\title{
Profesionalisme Guru dalam Membuat Soal Higher Order Thinking Skills
}

\author{
Armiati ${ }^{1, *}$, Muhammad Subhan ${ }^{2}$, Minora Longgom Nasution ${ }^{3}$, Saddam Al \\ Aziz $^{4}$, Maulani Meutia Rani ${ }^{5}$, Ronal Rifandi ${ }^{6}$, Yulyanti Harisman ${ }^{7}$ \\ 1,2,3,4,5,6,7 Departemen Matematika, Universitas Negeri Padang, Padang, Indonesia; \\ ${ }^{1 *}$ armiati math unp@yahoo.co.id
}

Info Artikel: Dikirim: 24 September 2019; Direvisi: 11 Februari 2020; Diterima: 4 Maret 2020 Cara sitasi: Armiati, A., Subhan, M., Nasution, L. M., Al Aziz S., Rani, M. M., Rifandi, R., \& Harisman, Y. (2020). Profesionalisme Guru dalam Membuat Soal Higher Order Thinking Skills. JNPM (Jurnal Nasional Pendidikan Matematika), 4(1), 75-84.

\begin{abstract}
Abstrak. Penelitian ini dilatarbelakangi rendahnya kemampuan Higher Order Thinking Skills (HOTS) siswa Sekolah Menengah Pertama (SMP). Profesionalisme guru sangat erat kaitannya dengan HOTS siswa. Penelitian ini bertujuan untuk menganalisis profesionalisme guru dalam membuat soal HOTS sebelum dan sesudah dilakukan pelatihan. Metode penelitian yang digunakan adalah metode survey. Tujuh belas guru dari 11 SMP se-Kecamatan Padang Utara, Sumatera Barat dijadikan sebagai subjek penelitian. Awalnya guru diminta membuat soal HOTS sebelum diberikan pelatihan. Selanjutnya, para pakar memberikan pelatihan dalam perancangan soal HOTS. Soal HOTS yang disusun oleh guru dianalisis sebelum dan sesudah mengikuti pelatihan. Hasil penelitian menunjukan bahwa $41 \%$ guru yang mampu membuat soal HOTS sebelum diberikan pelatihan. Soal HOTS yang dibuat oleh guru masih belum benar, karena kata kerja operasional pada soal masih berada pada level C1 - C2. Semua guru dapat membuat soal HOTS setelah diberikan pelatihan. Dari semua guru, 30 \% guru mampu memahami sebagian materi pelatihan dan mampu membuat soal HOTS namun masih belum benar dan $70 \%$ guru mampu memahami materi pelatihan dan mampu membuat soal HOTS dengan benar.
\end{abstract}

Kata Kunci: Higher Order Thinking Skills, Guru, Sekolah Menengah Pertama.

Abstract. This research was motivated by the low ability of Higher Order Thinking Skills
(HOTS) at Junior High School (SMP) students. Teacher professionalism is closely related to
students' HOTS. This study aimed to analyze how the professionalism of teachers in making
HOTS questions before and after the teacher's training programs. The research method used
was a survey method. Seventeen (17) teachers from 11 junior high schools in Padang Utara
District, West Sumatra, were used as research subjects. Initially, the teacher asked to make
HOTS questions before being given training programs. Furthermore, experts provided
training in the design of HOTS questions. HOTS questions compiled by the teacher were
analyzed before and after the training. There were forty-one (41) \% of teachers who already
made HOTS questions before given training programs. But, the teachers were still not
correct because the operational verbs in the problems were still at level C1 - C2. One 
hundred (100) \% of teachers had made HOTS questions after being given training programs. Of all the teachers, $30 \%$ of teachers were able to understand some of the training materials and were able to make HOTS questions but were still not correct, and $70 \%$ of teachers were able to understand the training materials and were able to make HOTS questions correctly.

Keywords: Higher Order Thinking Skills, Teacher, Junior High School.

\section{Pendahuluan}

Kemampuan berpikir tingkat tinggi sangat diperlukan oleh siswa baik siswa sekolah menengah pertama, siswa menengah atas maupun pada tingkat mahasiswa. Kemampuan berpikir tingkat tinggi siswa sekolah menengah pertama (SMP) masih rendah. Data ini dapat dilihat pada laporan hasil PISA (OECD, 2000) yang menyatakan bahwa untuk literacy matematika siswa sekolah menengah pertama sangat rendah. Rendahnya kemampuan literacy tersebut salah satu penyebabnya adalah rendahnya kemampuan berpikir tingkat tinggi siswa. Selanjutnya laporan OECD (2015) indonesia selalu menempati posisi terbawah dalam kemampuan literacy matematis siswa.

Hal ini perlu diatasi agar siswa Indonesia mampu meningkat prestasi mereka dalam ranking perolehan, baik PISA maupun dari laporan OECD. Salah satu cara mengatasi masalah tersebut adalah dengan meningkatkan kemampuan berpikir tingkat tinggi siswa (Abdullah, Haruzuan, Shukor, Atan, \& Halim, 2015; Arnellis, Jamaan, \& Amalita, 2018; Garcia, 2015; Kashefi, 2017; Khan \& Masood, 2015; Ping, Ahmad, Adnan, \& Hua, 2017; Pratama \& Retnawati, 2018; Ramesh \& Rao, 2015; Tanujaya, Mumu, \& Margono, 2017; Wimer, Ridenour, Thomas, \& Place, 2001). Jika dilihat dari beberapa penelitian yang dilakukan ahli, sudah sangat beragam usaha yang dilakukan untuk meningkatkan HOTS siswa. Samo, Darhim, \& Kartasasmita (2017) melakukan penelitian dengan mengembangkan model pembelajaran contextual yang valid, praktis, dan efektif untuk meningkatkan kemampuan HOTS siswa. Scott, Barbarin \& Brown (2013) Mengkaji pengaruh lingkungan sosial dengan HOTS siswa. Berdasarkan hasil penelitian Karimah, Kusmayadi, \& Pramudya (2018) diperoleh kesimpulan bahwa kesulitan siswa dalam mengerjakan soal HOTS geometri adalah berkaitan dengan aritmatika.

Selain dari penelitian-penelitian di atas, banyak pula penelitian yang menyorot bahwa profesionalisme guru dalam proses pembelajaran sangat berkaitan erat dengan HOTS siswa. Shukla (2016) melakukan studi yang memeriksa hubungan antara komponen profesional guru dengan keterampilan berpikir tingkat tinggi siswa. Hasil dari penelitian ini menyatakan bahwa profesionalisme guru dalam mengajar sangat berkaitan 
erat dengan HOTS siswa. Harisman, Kusumah, \& Kusnandi (2019a) dalam penelitiannya menyatakan bahwa guru yang excellent dalam pembelajaran akan menghasilkan siswa yang canggih dalam capaian pembelajarannya. Selanjutnya Richland \& Begolli (2016) melakukan analisis dan menemukan bahwa praktik guru di kelas akan mempengaruhi berpikir tingkat tinggi siswa. Susanti, Novia, Putra, \& Harisman (2012) menyatakan penerapan strategi yang tepat dalam pembelajaran juga akan meningkatkan HOTS siswa. Selanjutnya bahan ajar yang tepat juga dapat meningkatkan HOTS siswa (Harisman, 2014; Kariman, Harisman, Sovia, \& Prahmana, 2019)

Beberapa penelitian sudah mengkaji bagaimana profesionalisme guru dalam pembelajaran. Harisman, Kusumah, \& Kusnandi (2019b) telah melihat bagaimana guru meyakini pembelajaran dan siswanya. Guru yang meyakini pembelajaran yang dilakukan adalah proses konstruksi oleh siswa, akan mengajar dengan proses constructivism, sedangkan guru yang meyakini pembelajaran adalah proses transfer ilmu, maka guru akan mengajar dengan cara ceramah. Keyakinan guru akan berdampak pada capaian hasil belajar siswa salah satunya adalah cara berpikir tingkat tinggi siswa. Harisman, Kusumah, \& Kusnandi (2018) juga mengkaji bagaimana guru merefleksi proses pembelajaranya. Banyak tipe guru yang dideskripsikan pada penelitian ini, diantaranya terdapat guru yang tidak menyadari kesalahannya dalam mengajar, ada guru yang mampu merefleksi pembelajarannya namun tidak mampu memberikan rekomendasi cara belajar yang baik untuk memperbaiki kesalahan yang telah dilakukan, tipe selanjutnya adalah terdapat guru yang mampu merefleksi dan mampu memberikan solusi yang tepat terhadap proses pembelajaran yang telah dilakukan. Proses refleksi ini juga akan berpengaruh pada capaian siswa dalam proses pembelajaran di kelas dan pada akhirnya akan mempengaruhi capaian prestasi siswa.

Penelitian ini bertujuan untuk menganalisis profesionalisme guru sekolah menengah pertama se-Kecamatan Padang Utara, Indonesia dalam membuat soal HOTS. Penelitian ini akan menjawab pertanyaan penelitian: bagaimana soal HOTS yang dirancang guru tanpa diberikan pelatihan, kemudian bagaimana soal HOTS yang dirancang guru setelah dilakukan beberapa kali pelatihan oleh pakar yang memiliki koptensi pada bidang kajian tersebut. Penelitian-penelitian sebelumnya baru sebatas mengkaji bagaimana siswa mengerjakan soal HOTS. Masih jarang penelitian yang menganalisis bagaimana guru merancang soal HOTS yang akan diberikan kepada siswa. 


\section{Metode}

Metode pada penelitian ini adalah metode survey. Survey dilakukan untuk melihat peristiwa sebelum diberikan perlakuan dan setelah diberikan perlakuan. Partisipan dalam penelitian ini adalah 17 orang guru sekolah pertama dari seluruh sekolah menengah pertama se-Kecamatan Padang Utara dipilih sebagai subjek penelitian. Gambaran studi pada penelitian ini adalah setiap guru terlebih dahulu diminta untuk membuat soal HOTS. Selanjutnya guru diberikan pelatihan bagaimana cara merancang soal HOTS yang dilakukan oleh ahli yang memiliki kompetensi pada bidang tersebut. Setelah pelatihan selesai guru diminta kembali untuk merancang soal HOTS untuk siswa sekolah menengah pertama. Soal HOTS yang dibuat oleh guru baik sebelum maupun setelah pelatihan dianalisis dengan menggunakan rubrik pada Tabel 1.

Tabel 1. Rubrik Analisis Soal HOTS Guru

\begin{tabular}{|c|c|c|}
\hline \multicolumn{3}{|c|}{ Skala } \\
\hline 0 & 1 & 2 \\
\hline $\begin{array}{l}\text { Guru tidak mampu } \\
\text { memahami materi } \\
\text { pelatihan dan tidak } \\
\text { mampu membuat } \\
\text { soal HOTS }\end{array}$ & $\begin{array}{l}\text { Guru mampu memahami } \\
\text { sebagian materi pelatihan } \\
\text { dan mampu membuat soal } \\
\text { HOTS namun masih belum } \\
\text { benar }\end{array}$ & $\begin{array}{l}\text { Guru mampu memahami } \\
\text { materi pelatihan dan } \\
\text { mampu membuat soal } \\
\text { HOTS dengan benar }\end{array}$ \\
\hline
\end{tabular}

Hasil analisis akan disajikan dengan deskriptif dan dibahas dengan jelas pada tulisan ini.

\section{Hasil dan Pembahasan}

Berdasarkan hasil penelitian, diperoleh rekapitulasi persentase guru dalam membuat soal HOTS yang ditunjukkan oleh Tabel 2.

Tabel 2. Rekapitulasi Jumlah Guru yang Membuat Soal HOTS

\begin{tabular}{lcll}
\hline Sebelum Pelatihan & Jumlah & Setelah Pelatihan & Jumlah \\
\hline $\begin{array}{l}\text { Guru yang membuat Soal } \\
\text { HOTS Sebelum Pelatihan }\end{array}$ & 7 orang & $\begin{array}{l}\text { Guru yang membuat Soal } \\
\text { HOTS Setelah Pelatihan }\end{array}$ & 17 orang \\
$\begin{array}{l}\text { Guru yang tidak membuat Soal } \\
\text { HOTS Sebelum Pelatihan }\end{array}$ & 10 orang & $\begin{array}{l}\text { Guru yang tidak membuat } \\
\text { Soal HOTS Setelah Pelatihan }\end{array}$ & 0 orang \\
$\begin{array}{l}\text { Persentase Keberhasilan } \\
\text { Total Guru }\end{array}$ & $41(\%)$ & & $100(\%)$ \\
\end{tabular}

Tabel 2 menunjukan bahwa dari 17 guru yang menjadi subjek penelitian, terdapat 7 guru yang membuat soal HOTS dan 10 orang lagi belum membuat soal HOTS sebelum pelatihan. Alasan guru tidak membuat adalah 
belum paham. Selanjutnya sudah 17 guru yang membuat soal HOTS setelah pelatihan. Berdasarkan wawancara penulis dengan salah satu guru yang tidak membuat ketika ditanyakan alasannya dapat dilihat pada cuplikan wawancara berikut.

$\begin{array}{lll}\text { Pewawancara } & : & \text { Kenapa Ibu tidak membuat soal HOTS? } \\ \text { Guru } & : & \text { Saya belum paham apa itu soal HOTS } \\ \text { Pewawancara } & : & \text { Ibu pernah mendengar istilah kata kerja operasional pada soal? } \\ \text { Guru } & : & \text { Pernah, yang mengacu pada taksonomi C1 - C6 ya? } \\ \text { Pewawancara } & : & \text { Iya? Menurut Ibu kata kerja operasional soal HOTS itu pada } \\ & & \text { level apa? } \\ \text { Guru } & : & \text { Maksudnya apa ya? Saya kurang paham } \\ \text { Pewawancara } & : & \text { Oh, baiklah. Kalau stimulus pada soal ibu pernah dengar } \\ \text { Guru } & : & \text { Belum pernah }\end{array}$

Berdasarkan wawancara terlihat bahwa guru masih belum memahami kata level kata kerja operasional pada yang dapat digunakan ketika membuat soal HOTS. Berdasarkan cuplikan wawancara guru juga belum memahami apa yang dimaksud dengan stimulus pada soal. Berikut disajikan salah satu bentuk soal HOTS yang dibuat oleh guru sebelum diberikan pelatihan.

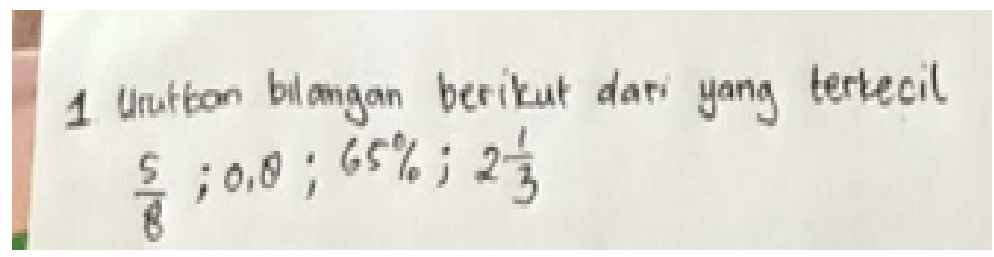

Gambar 1. Contoh Soal HOTS yang Dibuat Guru Sebelum Pelatihan

Gambar 1 memperlihatkan bahwa level soal yang dibuat guru masih berada pada level 2 yaitu dengan kata kerja menghitung. Belum tampak stimulus yang diberikan pada soal. Dari tujuh guru yang membuat soal HOTS hampir seluruh guru belum membuat soal yang kata kerja operasionalnya berada pada level 3-level 6.

Selanjutnya guru diberikan pelatihan cara perancangan soal-soal HOTS yang dilakukan oleh pakar yang memiliki kompetensi di bidangnya. Berdasarkan rubrik pada Tabel 2 diperoleh rekapitulasi hasil analisis kerja guru setelah dilakukan pelatihan yang dapat dilihat pada Tabel 3. 
Tabel 3. Rekapitulasi Pemahaman Guru setelah Diberikan Pelatihan

\begin{tabular}{|c|c|c|c|}
\hline Skala & Pencapaian & $\begin{array}{l}\text { Jumlah } \\
\text { Guru }\end{array}$ & $\begin{array}{c}\text { Persentase } \\
(\%)\end{array}$ \\
\hline 0 & $\begin{array}{l}\text { Guru tidak mampu memahami materi pelatihan } \\
\text { dan tidak mampu membuat soal HOTS }\end{array}$ & 0 & 0 \\
\hline 1 & $\begin{array}{l}\text { Guru mampu memahami sebagian materi } \\
\text { pelatihan dan mampu membuat soal HOTS } \\
\text { namun masih belum benar }\end{array}$ & 5 & 29 \\
\hline 2 & $\begin{array}{l}\text { Guru mampu memahami materi pelatihan dan } \\
\text { mampu membuat soal HOTS dengan benar }\end{array}$ & 12 & 70 \\
\hline \multicolumn{2}{|c|}{ Total Guru } & 17 & \\
\hline
\end{tabular}

Selanjutnya berikut disajikan salah satu bentuk soal HOTS yang sudah dibuat guru dengan benar setelah mengikuti pelatihan dapat dilihat pada Gambar 2 berikut.

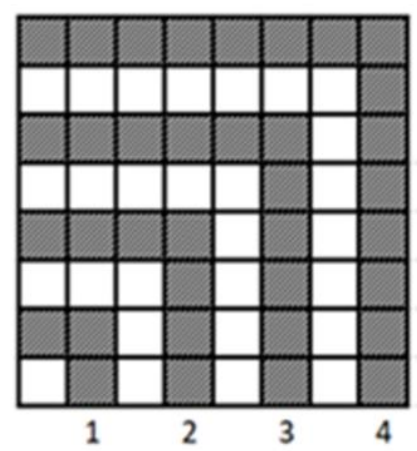

Pada gambar menunjukkan pola banyak persegi yang diarsir. Berapakah banyak persegi yang diarsir pada pola ke 20?

Gambar 2. Contoh Soal HOTS yang Dibuat Guru Setelah Pelatihan

Berdasarkan Gambar 2 guru sudah menunjukkan pemahamannya dalam merancang soal, dimana soal yang dibuat guru sudah berada pada level 4 . Pada level ini siswa sudah dituntut untuk dapat menganalisis pola apa yang muncul pada gambar berikutnya. Guru tersebut dapat dikategorikan pada guru yang memiliki skala pemahaman 2 .

Selanjutnya guru yang memiliki skala pemahaman 1 dapat dilihat pada Gambar 3. 
Soal

Fajar jalan-jalan ke Payakumbuh dan ia melihat sebuah menara. Fajar ingin mengetahui tinggi menara tersebut. Ia mengukur panjang bayangan menara yaitu $15 \mathrm{~m}$. Pada saat yang sama ia menancapkan sebuah tongkat yang panjangnya $5 \mathrm{~m}$ dan panjang bayangan tongkat tersebut setelah diukur adalah $3 m$. Berapakah tinggi menara yang dilihat Fajar?

Gambar 3. Contoh Soal HOTS yang Dibuat Guru Setelah Pelatihan

Berdasarkan Gambar 3 guru sudah mencoba memunculkan stimulus pada soal dan menggunakan kata kerja pada level C4 yang akan memberikan kesempatan kepada anak untuk melakukan analisis terhadap soal yang diberikan. Kesalahan yang dilakukan guru adalah stimulus yang diberikan masih belum tepat dan membuat anak bingung dalam menggambarkan kasus. Hal ini disebabkan karena kasus memberikan makna ambigu terhadap anak yang akan mencari solusi. Pemahaman guru dalam menyusun soal HOTS ini dapat diakibatkan karena pegetahuan guru tetang HOTS masih rendah (Retnawati, Djidu, Apino, \& Anazifa, 2018). Hasil penelitian ini juga menunjukkan bahwa guru matematika belum memiliki kemampuan yang baik dalam menjawab soal HOTS. Didis, Erbas, Cetinkaya, Cakiroglu, \& Alacaci (2016) menyatakan guru masih melakukan kesalahan dalam menilai kemampuan berpikir siswa dalam membuat model matematika dari masalah yang diberikan. Berikut hasil wawancara peneliti dengan guru yang membuat soal pada Gambar 3.

$\begin{array}{lll}\text { Pewawancara } & : & \text { Apakah soal yang Bapak/Ibu sajikan sudah benar? } \\ \text { Guru } & : & \begin{array}{l}\text { Menurut saya suda, karena kata kerja yang saya gunakan sudah } \\ \text { berada pada level 4, kemudian soal yang diberikan sudah memiliki } \\ \end{array} \\ & & \text { stimulus } \\ \text { Pewawancara } & : & \text { Apakah stimulus yang Bapak? Ibu berikan sudah benar? } \\ \text { Guru } & : & \text { Maksudnya?, oh iya menancapkan sebuah tongkat artinya } \\ & & \text { tongkat yang ditancapkan itu bisa lebih tinggi atau lebih rendah } \\ & & \text { dari menara dan dapat menutup bayangan menara ya? } \\ \text { Pewawancara } & : & \text { Iya benar sekali }\end{array}$

Dari wawancara tampak bahwa guru telah memahami kesalahan yang sudah dilakukan dalam menciptakan stimulus. Seman, Yusoff, \& Embong (2017) menyimpulkan bahwa guru perlu diberikan pelatihan ekstensif tentang HOTS. Tantangan terbesar bagi para guru ini adalah untuk mengajarkan sesuatu yang mereka tidak mengerti sepenuhnya; dan untuk mentransfer keterampilan yang tidak sepenuhnya mereka kuasai untuk 
siswa. Guru yang tidak mengerti HOTS tidak akan memiliki kompetensi dalam HOTS yang pada akhirnya akan mempengaruhi keterampilan mereka dalam mengajar HOTS. Selanjutnya, diperlukan pelatihan-pelatihan untuk meningkatkan profesionalisme guru. Profesionalisme tersebut dapat berupa kompetensi dalam merancang soal, pengajaran, dan pelatihan-pelatihan lainya. Penelitian ini sudah sejalan dengan penelitian Muir, Beswick, \& Williamson (2010); Muir \& Beswick (2007) yang menganggap perlu diberikan pelatihan kepada guru-guru dalam meningkatkan profesionalisme dalam pengajaran. Kedua penelitin ini dilakukan dengan memberi pelatihan untuk mendorong dan memberikan pelatihan dengan pendekatan Supportive Classroom Reflections (SCR). Konsep SCR adalah sebuah pendekatan yang menggabungkan proses pembelajaran profesional dengan praktek kelas yang dirancang untuk mendorong para guru untuk menafsirkan, merenungkan dan meningkatkan kemampuan mereka dalam pengajaran.

\section{Simpulan}

Berdasarkan hasil dan pembahasan maka kesimpulan dari penelitian ini adalah: guru membutuhkan pelatihan - pelatihan yang dapat mendorong mereka untuk meningkatkan profesionalisme dalam proses pembelajaran. Empat puluh satu (41) \% guru yang membuat soal HOTS sebelum diberikan pelatihan. Seratus (100) \% guru sudah membuat soal HOTS setelah diberikan pelatihan. Dari semua guru, $30 \%$ guru mampu memahami sebagian materi pelatihan dan mampu membuat soal HOTS namun masih belum benar dan $70 \%$ guru mampu memahami materi pelatihan dan mampu membuat soal HOTS dengan benar. Rekomendasi untuk penelitian lanjutan adalah peneliti lain dapat melakukan pelatihan - pelatihan terhadap kompetensi guru lain seperti IT dan sebagainya.

\section{Ucapan Terima kasih}

Terima kasih kepada Kemenristek Dikti Republik Indonesia dan Universitas Negeri Padang yang telah memberikan dukungan baik dukungan moril maupun materil terhadap penelitian ini.

\section{Daftar Pustaka}

Abdullah, Z., Haruzuan, M. N., Shukor, N. A., Atan, N. A., \& Halim, N. D. A. (2015). Enriching STEM curriculums with integration of MIT BLOSSOMS and Higher Order Thinking Skills (HOTS). ICEED 2014 - 2014 IEEE 6th Conference on Engineering Education, 111-116.

Arnellis, A., Jamaan, E. Z., \& Amalita, N. (2018). Efforts to Improve Mathematics Teacher Competency Through Training Program on Design Olympiad Mathematics Problems Based on Higher Order Thinking Skills in the Junior High School. IOP Conference Series: Materials Science and Engineering, 335(1), 1-5. 
Didis, M. G., Erbas, A. K., Cetinkaya, B., Cakiroglu, E., \& Alacaci, C. (2016). Exploring Prospective Secondary Mathematics Teachers' Interpretation of Student Thinking Through Analyzing Students' Work in Modelling. Mathematics Education Research Journal, 28 (3), 349-378.

Garcia, L. C. (2015). Biology Education and Research in a Changing Planet. Biology Education and Research in a Changing Planet, 45-54. Springer.

Harisman, Y., Kusumah, Y. S., \& Kusnandi, K. (2019a). Beliefs of Junior High School Teachers on Learning Process on Mathematical Problem Solving. Journal of Physics: Conference Series, 1157(3), 032112.

Harisman, Y., Kusumah, Y. S., \& Kusnandi, K. (2019b). How Teacher Professionalism Influences Student Behaviour in Mathematical Problem-Solving Process. Journal of Physics: Conference Series, 1188(1), 012080.

Harisman, Y., Kusumah, Y. S., \& Kusnandi, K. (2018). Teachers' Reflections on Students' Mathematical Problem Solving in Junior High School. Journal of Physics: Conference Series, 1088(1), 012011.

Harisman, Y. (2014). Validitas Dan Praktikalitas Modul Untuk Materi Fungsi Pembangkit Pada Perkuliahan Matematika Diskrit Di STKIP PGRI Sumatera Barat. AdMathEdu, 4(2), 207-214.

Kariman, D, Harisman, Y, Sovia, A, Prahmana RCI (2019). Effectiveness of Guided Discovery-Based Module: A Case Study in Padang City, Indonesia. Journal on Mathematics Education. 10(2), 239-250.

Karimah, R K N, Kusmayadi, T A, \& Pramudya, I. (2018). Analysis of Difficulties in Mathematics Learning on Students With Guardian Personality Type in ProblemSolving HOTS Geometry Test. J. Phys.: Conf. Ser, 1008 (012076).

Kashefi, H. (2017). Gender and Mathematics Performance of Primary Students in Higher Order Thinking Skills. 2017 7th World Engineering Education Forum (WEEF), 808-811. IEEE.

Khan, F. M. A., \& Masood, M. (2015). The Effectiveness of an Interactive Multimedia Courseware with Cooperative Mastery Approach in Enhancing Higher Order Thinking Skills in Learning Cellular Respiration. Procedia - Social and Behavioral Sciences, 176, 977-984.

Muir, T \& Beswick, K. (2007). Simulating Reflection on Practice: Using the Supportive Classroom Reflection Process. Journal Mathematics Teacher Education And Development. Spesial Issue (8), 74-79.

Muir, T, Beswick, K, \& Williamson, J. (2010). up, Close and Personal: Teachers' Response to an Individualised Professional Learning Opportunity. Asia-Pacifik Journal of Teacher Education, 38(2), Routledge Taylor\&Francis Group.

OECD. (2015). PISA result in Fokus. Paris: PISA - OECD Publishing.

OECD. (2000). PISA result in Fokus. Paris: PISA - OECD Publishing.

Ping, O. W., Ahmad, A., Adnan, M., \& Hua, A. K. (2017). Effectiveness of Higher Order Thinking Skills (HOTS) Based I-Think Map Concept Towards Primary Students. AIP Conference Proceedings, 1847, 10-12.

Pratama, G. S., \& Retnawati, H. (2018, September). Urgency of Higher Order Thinking Skills (HOTS) Content Analysis in Mathematics Textbook. Journal of Physics: Conference Series, 1097(1), 012147. IOP Publishing.

Ramesh, R., \& Rao, U. R. (2015). Investigating The Impact of In-Class Assignments on Higher Order Thinking Skills of Students In Engineering Course. Proceedings-2015 International Conference on Learning and Teaching in Computing and Engineering, LaTiCE 2015, 95-99. IEEE. 
Retnawati, H., Djidu, H., Apino, E., \& Anazifa, R. D. (2018). Teachers' Knowledge About Higher-Order Thinking Skills and Its Learning Strategy. Problems of Education in the 21st Century, 76(2). 215-230.

Richland, L E, \& Begolli K N. (2016). Analogy and Higher Order Thinking: Learning Mathematics as an Example. Policy Insights from the Behavioral and Brain Sciences, 3(2), 160-168.

Samo, D D, Darhim, \& Kartasasmita B. (2017). Developing Contextual Mathematical Thinking Learning Model to Enhance Higher-Order Thinking Ability for Middle School Students. International Education Studies, 10(12), 17 - 29.

Scott, K M, Barbarin O A, \& Brown J M. (2013). From Higher Order Thinking to Higher Order Behavior: Exploring the Relationship Between Early Cognitive Skills and Social Competence in Black Boys. American Journal of Orthopsychiatry, 83(2), 183-195.

Seman, S. C., Yusoff, W. M. W., \& Embong, R. (2017). Teachers Challenges in Teaching and Learning For Higher Order Thinking Skills (HOTS) in Primary School. International Journal of Asian Social Science, 7(7), 534-545.

Susanti, Novia, Putra, A A, Harisman Y. (2012). Pengaruh Penerapan Model Pembelajaran Kooperatif Tipe Think Pair Share (TPS) Disertai Handout Terhadap Pemahaman Konsep Matematis Siswa Kelas VIII SMPN 2 Rao Kabupaten Pasaman. e-Jurnal Mahasiswa Prodi Pend Matematika. 1(5), 1-10.

Shukla, D. (2016). Student's Perceived Level and Teachers' Teaching Strategies of Higher Order Thinking Skills; A Study on Higher Educational Institutions in Thailand. Journal of Education and Practice, 7(12), 2011 -2019.

Tanujaya, B., Mumu, J., \& Margono, G. (2017). The Relationship between Higher Order Thinking Skills and Academic Performance of Student in Mathematics Instruction. International Education Studies, 10(11), 78-85.

Wimer, J. W., Ridenour, C. S., Thomas, K., \& Place, A. W. (2001). Higher Order Teacher Questioning of Boys and Girls in Elementary Mathematics Classrooms. Journal of Educational Research, 95(2), 84-92. 